\title{
Micro-coagulation effects on direct ultrafiltration of challenging raw river water
}

\author{
Olga Ferrer, ${ }^{a^{*}}$ Remon Dekker, ${ }^{b}$ Jose Mesa, ${ }^{c}$ Jordi Martín-Alonso, ${ }^{c}$ José L \\ Cortina $^{\mathrm{a}, \mathrm{d}}$ and Oriol Gibert ${ }^{\mathrm{a}, \mathrm{d}}$
}

\begin{abstract}
BACKGROUND: The feasibility and competitiveness of substituting the conventional pre-treatment of drinking water treatment plants (dioxichlorination, coagulation/flocculation, settling, sand filtration) by raw river water direct ultrafiltration (UF) was addressed.

RESULTS: A full scale UF module was operated continuously for $\mathbf{2}$ years, treating highly variable surface water. The sustainable hydraulic conditions leading to a greater water yield from the direct UF treatment scheme under different scenarios were defined. Summer periods enabled the attainment of higher filtration fluxes, although raw river water showed greater turbidity and total suspended solids content. Winter periods presented higher dissolved organic carbon concentration, with greater

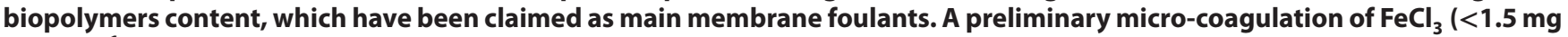
$\mathrm{Fe}(\mathrm{III}) \mathbf{L}^{-1}$ ) enabled supporting harsher hydraulic conditions and thus, implementing similar conditions throughout the year. Impacts of micro-coagulation were more pronounced on filtration, particularly in winter, but a positive effect was also noticed in hydraulic and chemical cleaning stages, increasing the efficiency of the former and decreasing by half the frequency of the latter.
\end{abstract}

CONCLUSION: Direct UF proved to be competitive with the current conventional pre-treatment, leading to a significant reduction in reagents needs and sludge production and an increased and more stable product water quality.

(c) 2016 Society of Chemical Industry

Keywords: ultrafiltration; fouling; water; quality; coagulation

\section{INTRODUCTION}

Freshwater scarcity has become a major concern in many arid and semi-arid countries worldwide to such an extent that meeting current and future water demand is one of the main challenges for mankind ${ }^{1}$. This requires the implementation of more efficient treatment schemes as well as processes capable of dealing with low quality resources. Low pressure membrane filtration has proven good removal capabilities which have led to its application within water treatment schemes. ${ }^{2}$ In drinking water treatment plants (DWTPs) dealing with surface water, ultrafiltration (UF) is typically implemented after a preliminary pre-treatment consisting of coagulation/flocculation, settling and granular media filtration, sometimes assisted by an initial disinfection. However, some studies have addressed the possibility of raw river water direct UF as an alternative to conventional pre-treatment for DWTPs. ${ }^{3-7}$ The associated envisaged advantages would be a decrease in reagents dosage and thus in solid waste generation, low footprint, ease of implementation due to its modularity ${ }^{8}$ as well as a decrease in the capital and operational expenses of a subsequent reverse osmosis (RO) stage. ${ }^{8}$

As stated above, previous work addressing the feasibility of direct UF can be found in the literature, but their experimental conditions as well as their outcomes differ. For instance, $\mathrm{Li}$ and Dong ${ }^{5}$ concluded that direct UF was not suitable to treat raw river water without any pre-treatment because the transmembrane pressure (TMP) increased quickly and the membrane became seriously fouled after $6 \mathrm{~h}$ of operation. Other $\sqrt{\mathrm{Q}}$ also faced technical difficulties when implementing direct UF, especially during high turbidity events. Clever et al. ${ }^{3}$ assessed direct UF of river water (unknown turbidity) by means of a dead end module $\left(35 \mathrm{~m}^{2}\right)$ for 10 months and reported some problems during high turbidity events when temperatures were below $10^{\circ} \mathrm{C}$. Pianta et al. ${ }^{9}$ worked with karstic spring water (mean turbidity 1.5 NTU but up to 130 NTU during storm events) both in dead end and cross-flow modes ( $7.2 \mathrm{~m}^{2}$ UF membrane surface area) for 12 months. It was concluded that direct UF (dead end mode) working at $140 \mathrm{~L} \mathrm{~m}^{-2} \mathrm{~h}^{-1}$ was appropriate for karstic waters with turbidity peaks below 20 NTU for a short period of time; under greater turbidity scenarios, cross-flow should be applied $\left(70 \mathrm{~L} \mathrm{~m}^{-2}\right.$

\footnotetext{
* Correspondence to: O Ferrer, CETaqua, Water Technology Center, Carretera d'Esplugues 75, 08940 Cornellà de Llobregat, Spain.

Email: oferrer@cetaqua.com

a CETaqua, Water Technology Center, Carretera d'Esplugues 75, 08940 Cornellà de Llobregat, Spain

b Pentair X-Flow, Pentair Water Process Technology BV, Marssteden 50, 7547 TC Enschede, The Netherlands

c AB, Aigües de Barcelona, General Batet 1-7, 08028 Barcelona, Spain

d Departament d'Enginyeria Química, ETSEIB, Universitat Politècnica de Catalunya, Av. Diagonal 647, 08028, Barcelona, Spain
} 
$\mathrm{h}^{-1}$ could be maintained over five consecutive days at mean turbidity of 40 NTU). On the other hand, other studies reported successful results, confirming the feasibility of UF as an alternative to coagulation, sedimentation/flotation and rapid sand filtration, ${ }^{10}$ being feasible especially for those waters with high variability in quality. ${ }^{6}$ For example, Rojas et al. ${ }^{6}$ worked with reservoir water (4-13 NTU) for 180 days at $54 \mathrm{~L} \mathrm{~m}^{-2} \mathrm{~h}^{-1}$ of filtration flux and $93 \%$ of water yield (ratio between net permeate produced and intaken water), Hofman et al. ${ }^{4}$ with canal water (12-40 NTU) for almost 1 year, at filtration flows of $70-100 \mathrm{~L} \mathrm{~m}^{-2} \mathrm{~h}^{-1}$, Vos et al. ${ }^{7}$ with canal water (20-70 NTU) for $11-30$ days at $50 \mathrm{~L} \mathrm{~m}^{-2} \mathrm{~h}^{-1}$, only achievable after optimizing the backwash and chemical cleaning operations, and Oosterom et al. ${ }^{10}$ with surface water of unreported quality, for $800 \mathrm{~h}$, obtained a large decrease in permeability (from $>400 \mathrm{~L} \mathrm{~m}^{-2} \mathrm{~h}^{-1}$ bar $^{-1}$ to $<50 \mathrm{~L} \mathrm{~m}^{-2} \mathrm{~h}^{-1}$ bar $^{-1}$ ) after $200 \mathrm{~h}$ of filtration. The reported water yields for UF of surface water without extensive pre-treatment were generally low; Schlichter et al. ${ }^{11}$ quantified them at $70-90 \%$. As can be seen, the initial experiences reported with successful results were performed for a few days/months ${ }^{6,7}$ and/or with raw water of relatively stable quality. ${ }^{4,6,7}$ As a consequence, their results cannot be extrapolated to full scale plants, which need to operate continuously, often with variable feed water. Due to the discrepancies in the conclusions drawn, together with the different conditions tested which make comparison of the results difficult, more research is needed to determine the feasibility of direct UF, to optimize its performance under different scenarios and finally to compare it with conventional pre-treatment.

A main limiting factor to the wider application of membrane filtration processes is fouling. ${ }^{2}$ Indeed, fouling results in an increased TMP and thus, more frequent cleaning is required. This in turn can cause membrane deterioration and decrease the process water yield. As a result, it becomes necessary to determine the fouling impact on real scale applications, as well as to define strategies to minimize its negative effects. Precoagulation has been defined as the most successful pre-treatment to reduce fouling on low pressure membranes. ${ }^{2}$ However, when combining coagulation and UF, the conditions and doses applied are not the same as those used in conventional water treatment ${ }^{2,12,13}$ being typically $40 \%$ or less. ${ }^{12}$ Studies on hybridizing precoagulation (with or without sedimentation) and UF can be found in the literature. ${ }^{14-16}$ These studies targeted total organic carbon (TOC) removal because UF presents a limited capacity to retain it. Increased TOC removal results in lower formation of disinfection byproducts (DBP) formation during the disinfection stage ${ }^{17}$.

This work addressed the implementation and optimization of direct UF treating highly variable raw river water, using a commercially available full scale module and operating continuously for 2 years. This represented intensive testing to ensure the feasibility of the proposed alternative, from sanitary and technical perspectives, paving the way for its future implementation in DWTPs. The effects of conducting a preliminary micro-coagulation were quantified in summer and winter periods, both at filtration and cleaning stages. Coagulant was dosed at micro-scale, just aiming at improving the subsequent filtration stage, which differs from the above-mentioned studies. In addition to this, due to the duration of the study, seasonal differences when coupling coagulation/UF were taken into account in a highly variable water source, complementing those studies as well. Conventional fouling mechanism laws were considered, in order to identify where a different blocking law applied in each case, and thus, could explain the differences encountered.

\section{EXPERIMENTAL}

\section{Experimental set up}

The experimental set up consisted of a prototype plant equipped with a strainer $(300 \mu \mathrm{m})$ followed by a pressurized inside-out UF membrane system (Pentair X-Flow Aquaflex module, dead end mode, polyethersulfone (PES), $20 \mathrm{~nm}$ pore size) automatically controlled by a supervisory control and data acquisition (SCADA) system (Appendix). The prototype worked at constant permeate flow and had a nominal capacity of $5.0 \mathrm{~m}^{3} \mathrm{~h}^{-1}$. It filtered Llobregat river water directly and continuously for 2 years (May 2011 ril 2013). The filtration process was automatically stopped when a pre-set value of either TMP (1 bar) or hydraulic resistance $\left(1.0 \mathrm{E}^{+13} \mathrm{~m}^{-1}\right)$ was reached. More details about the experimental set up can be found in a previous work. ${ }^{18}$ The prototype plant was installed in Sant Joan Despí DWTP (Barcelona metropolitan area, Spain) and its performance was compared with its current pre-treatment, consisting of dioxichlorination, coagulation/flocculation, settling and sand filtration. The Llobregat River presents a typical Mediterranean behaviour, experiencing large flow fluctuations (severe droughts during summer and flash flood events in spring and autumn) with its associated water quality variations, and also suffers from historical industrial and urban contamination. ${ }^{19}$ This provides a challenging scenario to conduct feasibility studies of water treatment technologies.

During the whole 2 year period studied the hydraulic cleaning $(\mathrm{HC})$ and the chemically enhanced backwash (CEB) sequences were not modified. The HC involved a forward flush of $62.5 \mathrm{~L} \mathrm{~m}^{-2}$ $\mathrm{h}^{-1}$ for $20 \mathrm{~s}$, a UF permeate backwash flux of $250 \mathrm{~L} \mathrm{~m}^{-2} \mathrm{~h}^{-1}$ for $20 \mathrm{~s}$ enhanced by an airflush of $10 \mathrm{Nm}^{3} \mathrm{~h} \mathrm{~L}^{-1}$ for $10 \mathrm{~s}$ and a final forward flush of $62.5 \mathrm{~L} \mathrm{~m}^{-2} \mathrm{~h}^{-1}$ for $40 \mathrm{~s}$. The CEB was composed of a basic-oxidizing stage $(\mathrm{NaOH}$ [49/50\%, Severn Trent, Spain] and $\mathrm{NaClO}$ [Severn Trent, Spain] dosing) and an acid stage ( $\mathrm{HCl}$ [15\%, Severn Trent, Spain] dosing) subsequently. The CEB sequence consisted in an $\mathrm{HC}$, a basic-oxidizing dosing $\left(125 \mathrm{~L} \mathrm{~m}^{-2} \mathrm{~h}^{-1}, 45 \mathrm{~s}\right)$, a soaking with those chemicals $(10 \mathrm{~min})$, a rinsing $\left(250 \mathrm{~L} \mathrm{~m}^{-2} \mathrm{~h}^{-1}\right.$, $45 \mathrm{~s})$, an acid dosing $\left(125 \mathrm{~L} \mathrm{~m}^{-2} \mathrm{~h}^{-1}, 45 \mathrm{~s}\right)$, a soaking with that chemical (10 $\mathrm{min})$ and a rinsing $\left(250 \mathrm{~L} \mathrm{~m}^{-2} \mathrm{~h}^{-1}, 45 \mathrm{~s}\right)$ stage. Alkaline solution $(\mathrm{NaOH})$ concentration was $480 \mathrm{mg} \mathrm{L}^{-1}$, oxidizer $(\mathrm{NaClO})$ $200 \mathrm{mg} \mathrm{L}^{-1}$ and acid (HCl) $438 \mathrm{mg} \mathrm{L}^{-1}$.

Non-coagulation and coagulation periods were tested in order to assess the differences in hydraulic behaviour of the UF membrane. In the latter case, in-line micro-coagulation was conducted just before the feed pumping system, so that the turbulence created by the pump ensured the adequacy of the hydraulic conditions. It was termed micro-coagulation because the doses applied $\left(<1.5 \mathrm{mg} \mathrm{L}^{-1} \mathrm{Fe}(\mathrm{III})\right)$ were well below those required for conventional coagulation purposes $\left(20-35 \mathrm{mg} \mathrm{L}^{-1}\right.$ of $\mathrm{Fe}$ (III) according to Edzwald ${ }^{20}$ for $\mathrm{pH} 8.0$ (raw river water average) and dissolved organic carbon (DOC) content of 4.4 and $7.3 \mathrm{mg} \mathrm{C} \mathrm{L}^{-1}$ (summer and winter, respectively)). The aim of the micro-coagulation was to aid filtration rather than to decrease the DOC content. The micro-coagulation dose was controlled by a dynamic smart control system (ViCA software) developed by Pentair. More details can be found in Blankert et al. ${ }^{21}$ but basically this system adjusted the coagulant dose based on the hydraulic resistance trend after each HC. The coagulant tested was ferric chloride (40\%, Severn Trent, Spain).

\section{Water quality characterization}

Both Llobregat River water and membrane permeate stream were analysed on a periodic basis. The parameters monitored 
and the methods used were: temperature by resistivity (Endress \& Hausser TR10-ABG1HD-SAG2000), conductivity by electrometry (Endress \& Hausser CLS21D-C1 + CM42-KAA000EAN00), pH by potentiometry (Hach-Lange DPD1P.99), turbidity by nefelometry (Hach-Lange Ultraturb SC), total suspended solids (TSS) by ESS 340.2, absorbance at $254 \mathrm{~nm}\left(\mathrm{UV}_{254}\right)$ by spectrophotometry (Hach-Lange DR 5000), silt density index $\left(\mathrm{SDI}_{15}\right)$ and modified fouling index $\left(\mathrm{MFI}_{0.45}\right)$ by ASTM D4189 (Simple SDI Meter 9C-281-0157), DOC by combustion-infrared method using a DOC analyser (non-purgeable organic carbon, UNE-EN 1484), after filtration with a $1.2 \mu \mathrm{m}$ glass fibre filter of the raw water samples (TOC-V CSH Shimadzu), particle size distribution by laser beam extinction (HIAC Royco, Pacific Scientific), total coliforms, faecal coliforms and E. coli quantification by the defined substract method (most probable number) and Clostridium perfringens and aerobic bacteria at $22^{\circ} \mathrm{C}$ by plate counting.

Fractionation of DOC was performed by high performance size exclusion chromatography (HPSEC) using a Toyopearl TSK HW-50S column $(250 \times 20 \mathrm{~mm})$ coupled to on-line $\mathrm{UV}_{254}$, organic carbon and organic nitrogen detectors by DOC-Labor (Karlsruhe) as described in Huber et al. ${ }^{22}$ The main fractions obtained by these analyses were the non-chromatographic (HOC), and the chromatographic, which in turn was classified into (a) biopolymers (BP) (molecular weight (MW) $>20000 \mathrm{~g} \mathrm{~mol}^{-1}$, basically constituted of polysaccharides and proteins); (b) humic substances (HS) (MW approx. $1000 \mathrm{~g} \mathrm{~mol}^{-1}$, constituted of fulvic and humic acids); (c) building blocks (BB) (MW between 300 and $500 \mathrm{~g} \mathrm{~mol}^{-1}$, constituted of breakdown products of humics); (d) low molecular weight acids (LMWA) (MW $<350 \mathrm{~g} \mathrm{~mol}^{-1}$, constituted of alcohols, aldehydes, ketones, sugars and amino acids); (e) low molecular weight neutrals (LMWN) (MW $<350 \mathrm{~g} \mathrm{~mol}^{-1}$, constituted of alcohols, aldehydes, ketones and amino acids).

Fluorescence excitation-emission matrix (EEM) spectroscopy analyses were conducted by Aigües de Barcelona by means of a LS 55 Perkin Elmer fluorescence spectrophotometer. Emission and excitation wavelengths ranges were $230-650 \mathrm{~nm}$ and $225-515 \mathrm{~nm}$, respectively, with a step width of $10 \mathrm{~nm}$, a scan velocity of $600 \mathrm{~nm} \mathrm{~s}^{-1}$; slit widths of excitation and emission were held constant during all measurements (slit ex/slit em 5/5). All samples except the permeate were filtered $(0.45 \mu \mathrm{m})$ before being analysed by EEM. Regions defined by Chen et al..$^{23}$ were used to identify different DOC fractions.

Airflow tests were conducted at least once a month to verify the membrane integrity, following the membrane manufacturer protocol. The membrane module was drained, the valves surrounding the membrane housing were closed, the membrane feed side was pressurized at 1 bar for $5 \mathrm{~min}$ and a valve on the permeate side was opened. The air flow passing through that valve was continuously registered. If the airflow was greater than $0.2 \mathrm{Nm}^{3} \mathrm{~h}^{-1}$, it indicated that the membrane had been compromised, since air was not only diffusing through the membranes, but also passing through broken fibres.

\section{Calculations and data treatment}

Hydraulic resistance $(\mathrm{R})\left(\mathrm{m}^{-1}\right)$, which accounted for the membrane resistance itself as well as the resistance offered by the accumulated foulants, was used to characterize the UF membrane hydraulic performance, calculated by the Darcy equation. HC and CEB cleaning efficiencies of each cycle $\left(\eta_{\mathrm{HC}}\right.$ and $\eta_{\mathrm{CEB}}$, respectively) (dimensionless) were calculated as shown in Equation (1) and (2), respectively, where $R_{\text {after the previeous CEB }}$ Corresponds to the hydraulic resistance after the last CEB conducted $\left(\mathrm{m}^{-1}\right), \mathrm{R}_{\text {after the } \mathrm{HC}}$ to the hydraulic resistance after the $\mathrm{HC}$ under consideration $\left(\mathrm{m}^{-1}\right), \mathrm{R}_{\text {after the CEB }}$ to the hydraulic resistance after the CEB under consideration $\left(\mathrm{m}^{-1}\right)$ and $R_{M}$ to the virgin membrane resistance $\left(6.0 \mathrm{E}^{+11} \mathrm{~m}^{-1}\right)$.

$$
\begin{gathered}
\eta_{\mathrm{HC}}=\frac{\mathrm{R}_{\mathrm{after} \text { the previous CEB }}}{\mathrm{R}_{\text {after the } \mathrm{HC}}} \\
\eta_{\mathrm{CEB}}=\frac{\mathrm{R}_{\mathrm{M}}}{\mathrm{R}_{\text {after the CEB }}}
\end{gathered}
$$

Specific cake resistance $(\alpha)\left(\mathrm{m}^{-2}\right)$, which represents the increase of the cake layer resistance build up, was calculated by Equation (3), where $v$ is the specific volume $\left(\mathrm{m}^{3} \mathrm{~m}^{-2}\right)$, which is the filtered volume $(V)\left(\mathrm{m}^{3}\right)$ per unit area, $A$ is the membrane surface area $\left(55 \mathrm{~m}^{2}\right), J$ is the water flux $\left(\mathrm{m}^{3} \mathrm{~m}^{-2} \mathrm{~s}^{-1}\right)$ and $t$ is the time (s).

$$
\alpha=\frac{d R}{d v}=\frac{d R}{d\left(\frac{v}{A}\right)}=\frac{1}{J} \cdot\left(\frac{d R}{d t}\right)
$$

Due to the high frequency of data acquisition within the prototype plant as well as the duration of the experiments (2 years), very large amounts of data were obtained. Consequently, an Excel (Microsoft) macro reducing it while keeping its representativeness was applied. One month physico-chemical, microbiological and operational parameters were considered for the comparison between winter/summer, coagulation/no coagulation periods, representative of each condition considered. Confidence intervals of $95 \%$ were used to provide information on the variability of values, and a significance of 0.05 was applied to calculate differences among data sets (by means of Mintab).

\section{RESULTS AND DISCUSSION}

Direct ultrafiltration feasibility and performance

Direct UF feasibility and permeate quality obtained

Continuous operation of the direct UF scheme for 2 years demonstrated the feasibility of this configuration as an alternative to conventional drinking water pre-treatment processes (dioxichlorination, coagulation/flocculation, settling and sand filtration). The configuration proposed was able to continuously treat raw river water, independently of its fluctuations (e.g. turbidity ranging from 5 up to $>1000 \mathrm{NTU}$, DOC between 2 and $14 \mathrm{mg} \mathrm{C} \mathrm{L}^{-1}$ and $\mathrm{UV}_{254}$ from 0.062 to $0.430 \mathrm{~cm}^{-1}$ ) delivering product water of constant quality, equal or superior to the conventiopally pre-treated one for most of the parameters monitored (Table 4. ig. 1). In particular, turbidity $(0.068 \pm 0.004$ vs. $0.313 \pm 0.031 \mathrm{NTU})$, TSS $(0.92 \pm 0.17$ vs. $1.03 \pm 0.16 \mathrm{mg} / \mathrm{L}), \mathrm{SDI}_{15}(1.90 \pm 0.15$ vs. $5.20 \pm 0.13 \% / \mathrm{min}), \mathrm{MFI}_{0.45}$ $\left(0.85 \pm 0.73\right.$ vs. $\left.25.18 \pm 11.35 \mathrm{~L} / \mathrm{s}^{2}\right)$ and the microbiological parameters considered presented lower concentrations in the direct UF permeate. Microbiological parameters assessed were consistently absent in the UF permeate, except for the aerobic bacteria at $22^{\circ} \mathrm{C}$. Their occurrence could be due to their environmental presence, which could lead to the formation of a biofilm that could be released to some extent while sampling, rather than to their passage through the membrane. Concentrations up to $6.21 \log _{10}$ (MPN per $100 \mathrm{~mL}$ ) of total coliforms, $5.38 \log _{10}$ (MPN per $100 \mathrm{~mL}$ ) of faecal coliforms, $5.20 \log _{10}$ (MPN per $100 \mathrm{~mL}$ ) of E. coli and $4.96 \log _{10}$ (MPN per $100 \mathrm{~mL}$ ) of Clostridis perfringens, which were the maximum values quantified in the raw river water, were completely removed by the direct UF scheme.

On the other hand, the DOC and the $U_{254}$ were removed to a larger extent by the conventional pre-treatment, their values being 


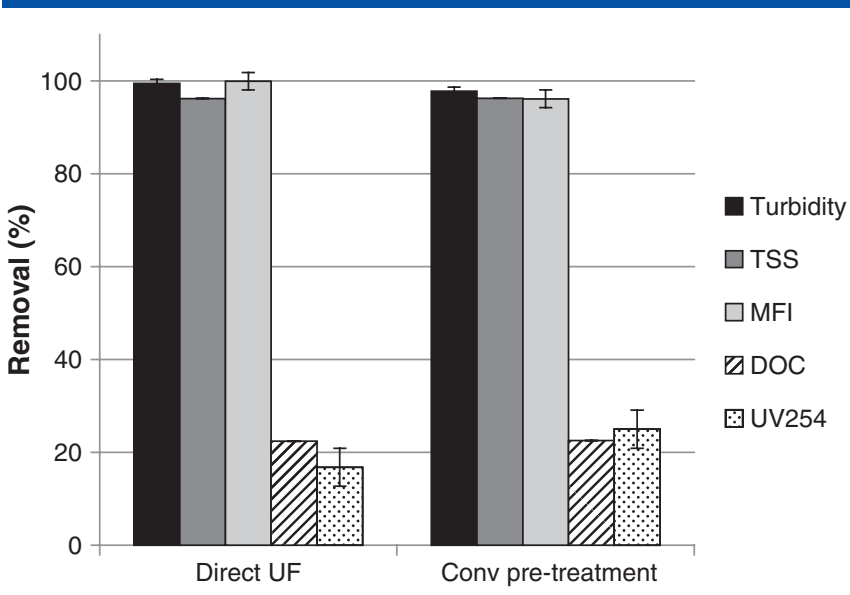

Figure 1. Removal percentage of various physico-chemical paramete by the direct UF and the conventional pre-treatment schemes. SDI removal could not be calculated because raw river water SDI1 above high level $\left(>6 \% \mathrm{~min}^{-1}\right)$. Error bars correspond to the $\mathrm{E}$ d error (number of samples: 347 for turbidity, 118 for TSS, 100 for MFI, 70 for DOC, 350 for UV25

$$
\bar{\equiv}
$$

after direct UF and conventional pre-treatment $3.77 \pm 0.16$ vs $3.51 \pm 0.19 \mathrm{mg} \mathrm{L}^{-1}$ and $0.0815 \pm 0.0018$ vs $0.0725 \pm 0.0028 \mathrm{~cm}^{-1}$, respectively. In general, less variability was presented in the direct UF scheme, leading to a more stable process under all conditions considered. It is important to remember that direct UF would substitute the conventional pre-treatment and thus, subsequent stages (e.g. reverse osmosis and final disinfection) would be needed to meet the drinking water requirements.

From a qualitative standpoint and according to Chen et $a .^{23} \mathrm{EEM}$ spectra regions classification (Fig. 2) shows that raw river water mainly contained microbial by-products (represented in region IV), humic acid-like compounds (region V), fulvic acid- like substances (region III) and aromatic proteins (regions I and II). This is in accordance with the HPSEC DOC fractionation results obtained (Fig. 3).

The UF membrane was able to partially remove some DOC, as depicted in Fig. 1 and Fig. 2 (DOC feed $6.8 \mathrm{mg} \mathrm{L}^{-1}$ and DOC permeate $5.2 \mathrm{mg} \mathrm{L}^{-1}$ ), but the permeate still contained the different dissolved organic fractions identified, although to a lesser extent. Comparing the raw river water and the $\mathrm{HC}$ streams it can be seen that signals from region IV, I and II were similar in both cases, indicating that microbial by-products and aromatic proteins were retained by the membrane and were detached by the $\mathrm{HC}$.

The basic-oxidizing CEB mostly removed microbial by-products, some fulvic acid-like substances and aromatic proteins, whereas the acid CEB removed fulvic acid like compounds and some proteins, mainly. The DOC concentration of the basic-oxidizing CEB was $28.4 \mathrm{mg} \mathrm{L}^{-1}$ and the acid one $6.9 \mathrm{mg} \mathrm{L}^{-1}$, showing the significantly higher efficiency of the former in terms of overall organic foulants removal. The lower removal capacity of the acid CEB can be explained by two factors. First, organic foulants are mainly detached from the membrane by basic and/or oxidizing agents, as widely reported in the literature. Second, the acid CEB was conducted after the basic-oxidizing one, so that some foulants might have already been eliminated, leading to lower removal efficiency.

Airflow tests as well as membrane integrity tests with virus surrogates following the procedure described in Ferrer et al. ${ }^{24}$ were periodically carried out (every 1 and 3 months respectively). They both indicated that the membrane integrity had not been compromised, because the airflow registered $\left(0.051 \pm 0.006 \mathrm{Nm}^{3} \mathrm{~h}^{-1}\right)$ during the airflow integrity tests was well below the threshold defined by the membrane manufacturer as indicative of a breach $\left(0.2 \mathrm{Nm}^{3} \mathrm{~h}^{-1}\right)$ and there was no increase of microbes passage in the tailored tests performed over time (data not shown).

It was not possible to determine by multi-variant analyses clear relationships between the hydraulic resistance evolution and several physico-chemical feed water parameters, such as turbidity, $\mathrm{pH}$, conductivity, temperature, water viscosity, as well as operational parameters, such as HC frequency, filtration time, etc. An empirical model capable of predicting the hydraulic resistance behaviour based on the collected data could not be defined. The difficulties encountered in the modelling study suggested a set of processes occurring, turning into a complex system probably aggravated by the challenging raw river water tested. Despite the impossibility of obtaining a reliable model describing and predicting hydraulic resistance evolution, the influence of physico-chemical parameters on the UF performance was studied in detail.

\section{Direct UF operational performance}

Optimal operational conditions aiming at maximizing the water yield and the filtration flux maintaining the UF TMP below 1 bar and the resistance below $1.0 \mathrm{E}^{+13} \mathrm{~m}^{-1}$ were established (Table 1). The highest water yields achieved ranged between $94.0 \%$ and 94.7\% under optimal conditions, involving one or two CEBs per day, TMP below 1 bar and filtration fluxes of $40-70 \mathrm{~L} \mathrm{~m}^{-2}$ $\mathrm{h}^{-1}$. Reagents consumption per cubic meter of feed water was $0.6-2.1 \mathrm{~mL} \mathrm{NaOH} \mathrm{m}{ }^{-3}, 1.2-4.3 \mathrm{~mL} \mathrm{NaClO} \mathrm{m}^{-3}, 2.5-8.6 \mathrm{~mL} \mathrm{HCl} \mathrm{m}^{-3}$ (CEBs) and $0-1.5 \mathrm{mg} \mathrm{Fe}(\mathrm{III}) \mathrm{L}^{-1}$ (micro-coagulation). These values were competitive with the current conventional pre-treatment, since water losses of the latter accounted for $5 \%$ and the chemical consumption for $32.2 \mathrm{mg}$ PAX-18 $\mathrm{L}^{-1}$ and $2 \mathrm{mg} \mathrm{ClO}_{2} \mathrm{~L}^{-1}$ for the period considered. Consequently, the waste generation would be greater in the conventional pre-treatment scheme. Finally, the direct UF scenario enabled the treatment of raw river water regardless of its quality. The conventional pre-treatment was typically stopped when turbidity was above 500-1000 NTU to avoid destabilizing the system, whereas the direct UF scheme enabled continuous operation, even for values greater than 1000 NTU.

As can be seen in Table 1, the UF behaviour differed between winter and summer, as well as when micro-coagulation was applied. These differences could be due to the membrane itself (e.g. polymer properties) and the water characteristics (e.g. temperature, natural organic matter (NOM) content and composition, inorganic compounds concentration).

In general, during summer periods greater filtration fluxes could be applied in a sustainable way. However, the lower filtration flux achievable in winter could be counterbalanced by a longer filtration time, leading to a similar water yield. The higher attainable filtration fluxes could be due to the higher temperatures in summer, involving lower water viscosity and thus, lower TMP for a given flux. Nevertheless, seasonal differences in fouling nature and content, encompassed within the hydraulic resistance term, could also contribute to this behaviour. Appendix, Table Ay sum-

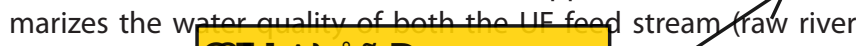
water) and th \$SSHOG $\square$. 51 month in each of the situations stuarea. Desple the vartadilty of the Llobregat River, the temperature $\left(26.5\right.$ vs $\left.8.9^{\circ} \mathrm{C}\right)$, turbidity $(163.4 \pm 144.1$ vs $21.8 \pm 5.4 \mathrm{NTU})$, TSS $\left(239.1 \pm 265.3\right.$ vs $\left.23.4 \pm 10.4 \mathrm{mg} \mathrm{L}^{-1}\right)$, SUVA $\left(2.2 \pm 0.2\right.$ vs $\left.1.8 \pm 0.5 \mathrm{~L} \mathrm{mg}^{-1} \mathrm{~cm}^{-1}\right)$ and $\mathrm{MFI}_{0.45}(3897.8 \pm 3697.0$ vs $637.9 \pm 656.6 \mathrm{~L} \mathrm{~s}^{-2}$ ) tended to be higher in summer than in winter, whereas the DOC, lower $\left(4.4 \pm 0.8\right.$ vs $\left.7.3 \pm 3.7 \mathrm{mg} \mathrm{C} \mathrm{L}^{-1}\right)$. 

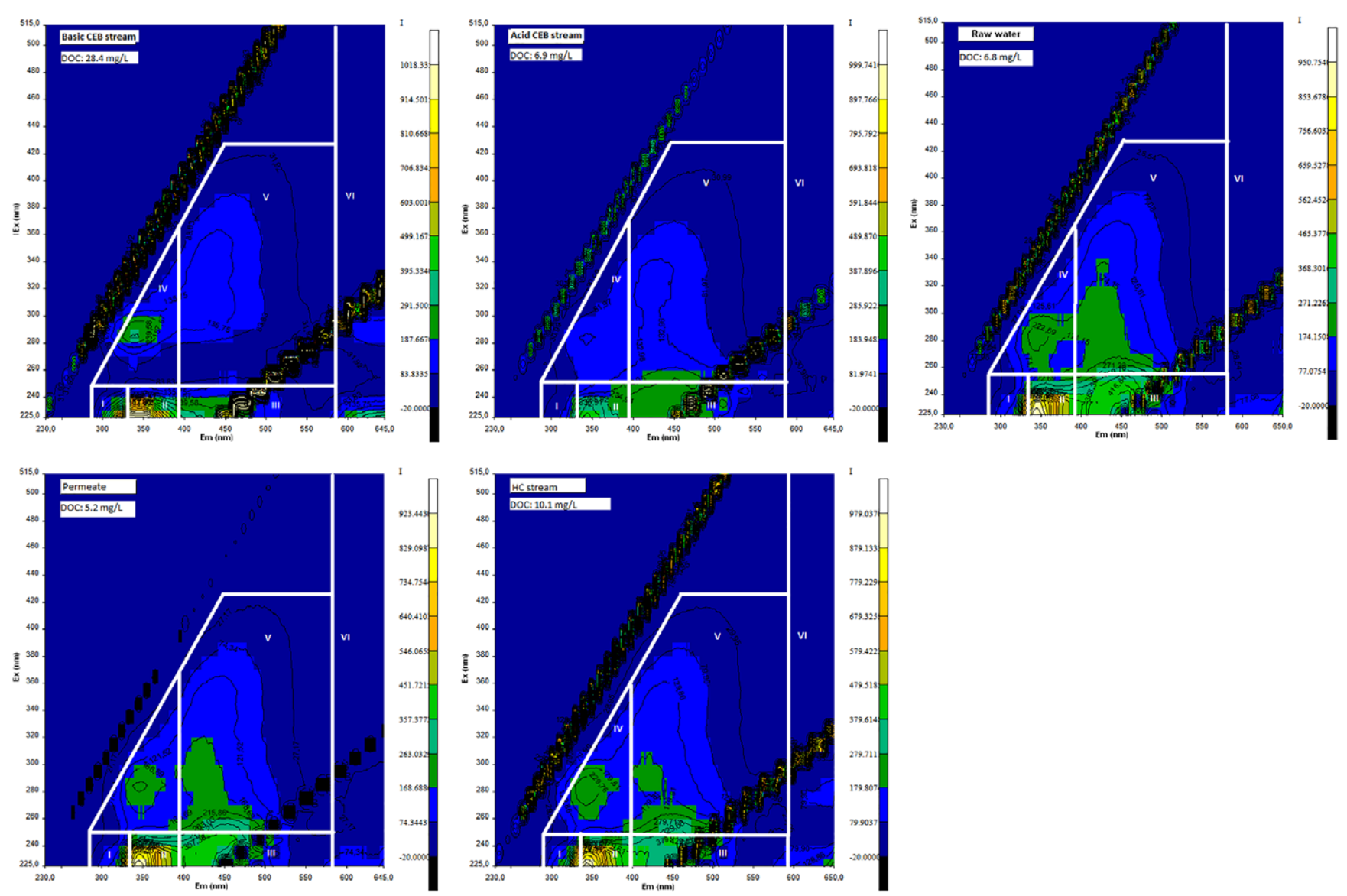

Fig (re). Fluorescence excitation-emission matrix (EEM) spectroscopy results of different UF membrane streams; from left to right, at the top: raw river wat, permeate and hydraulic cleani, the bottom: basic-oxidizing CEB and acid CEB.

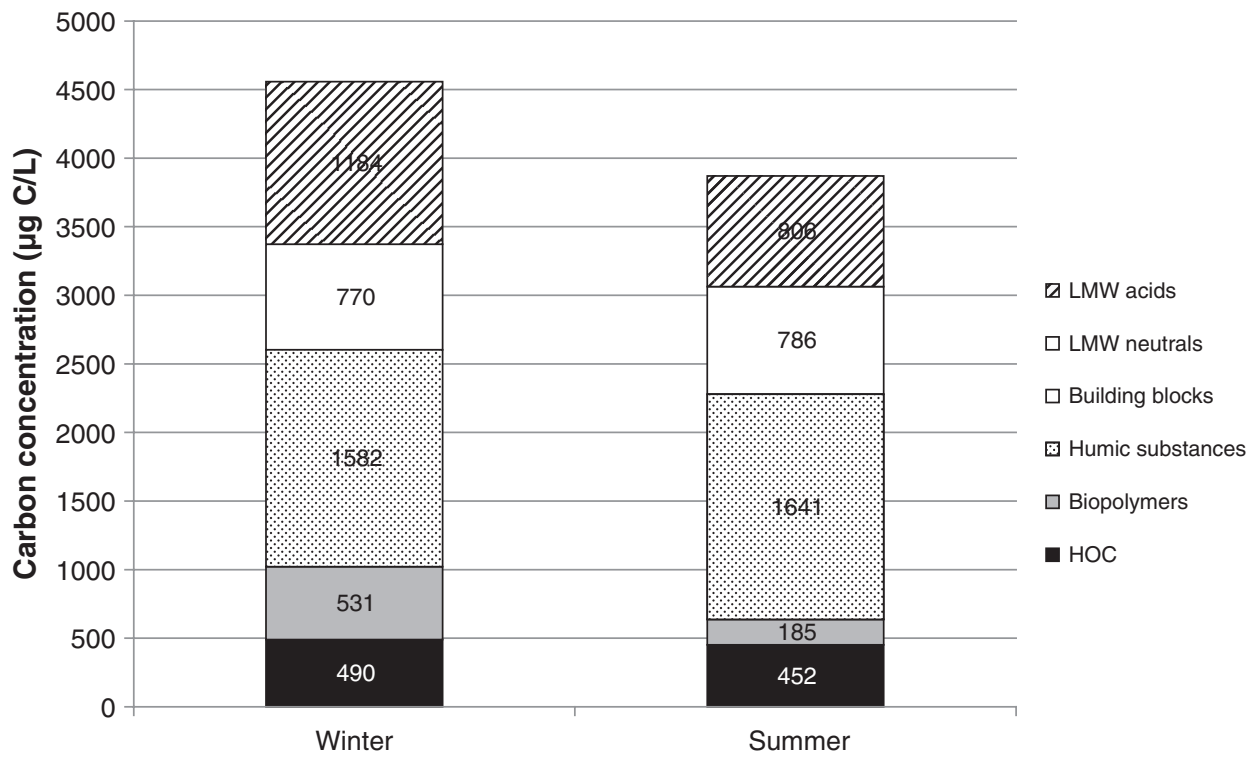

Figure 3. Raw river water DOC fractionation in winter and summer time. Numbers in the boxes indicate the concentration of each fraction in $\mu \mathrm{g} C \mathrm{~L}^{-1}$.

Particle size distribution showed a larger particle content in summer than in winter $(449421 \pm 19953$ vs $150777 \pm 55969$ particles $\mathrm{mL}^{-1}$ ), which is in accordance with the greater TSS content. Nevertheless, the percentage of smaller particles was higher in winter. Some of the parameters mentioned have been reported to impact membrane performance, which may explain the seasonal differences encountered. Low temperatures $\left(6.5-11^{\circ} \mathrm{C}\right)$ have been reported to accelerate irreversible fouling. ${ }^{25}$ Cakes formed by smaller particles (whose percentage was higher in winter) are more compact and less porous, ${ }^{26}$ presenting a greater 


\begin{tabular}{|lcccc|}
\hline $\begin{array}{l}\text { Table 1. Optimal operational conditions defined during the } 2 \text { year } \\
\text { operation }\end{array}$ & Summer & \multicolumn{4}{c|}{ Winter } \\
\hline Season & No & Yes & No & Yes \\
\hline $\begin{array}{l}\text { Micro-coagulation } \\
\text { applied? }\end{array}$ & 70 & 70 & 40 & 70 \\
$\begin{array}{c}\text { Filtration flux } \\
\quad\left(\mathrm{L} \mathrm{m}^{-2} \mathrm{~h}^{-1} \text { ) }\right.\end{array}$ & 45 & 45 & 120 & 45 \\
$\begin{array}{c}\text { Filtration } \\
\text { duration (min) }\end{array}$ \\
$\begin{array}{l}\text { TMP range (bar) } \\
\text { CEB frequency } \\
\quad \text { (\# CEB day }{ }^{-1} \text { ) }\end{array}$ & $0.16-0.73$ & $0.14-0.97$ & $0.13-0.62$ & $0.35-0.79$ \\
Water yield (\%) & 94.0 & 94.7 & 94.5 & 94.7 \\
\hline
\end{tabular}

resistance, according to the Carman-Kozeny equation. DOC content was identified as the most detrimental component in terms of fouling when filtering surface water ${ }^{27}$ and its concentration was higher in winter. In particular, DOC fractionation results (Fig. 3) showed higher biopolymers (BPs) and low molecular weight neutrals (LMWN) concentration in winter compared with summer. This could partially explain the seasonal differences experienced in membrane filtration performance, since BPs have been described as main membrane foulants ${ }^{28}$ and low molecular weight molecules are known to cause high specific cake resistance. ${ }^{29}$

Although SDI and MFI are used to assess the fouling potential in RO membranes and SDI is intended for water samples with turbidity below $1 \mathrm{NTU}^{30}$ it could be questioned if these parameters could also provide insights into the fouling propensity of UF membranes. Within this study, higher fouling index values $\left(\mathrm{SDI}_{15}\right.$ and $\mathrm{MFI}_{0.45}$ ) were encountered in raw river water during summer periods, which would suggest greater UF membrane fouling. However, the hydraulic resistance increase rate was higher in winter (see section Coagulant effect on hydraulic resistance evolution during filtration cycles) and thus the assessed membrane was able to sustain higher filtration fluxes in summer, suggesting that SDI ${ }_{15}$ and $\mathrm{MFI}_{0.45}$ could not be used for such a purpose. Some limitations of both indexes have been reported in the literature when used as indicators of RO fouling propensity. ${ }^{31}$

A micro-coagulation step prior to the UF unit had a positive impact on the filtration fluxes attainable in winter $\left(40 \mathrm{~L} \mathrm{~m}^{-2}\right.$ $\mathrm{h}^{-1}$ vs $70 \mathrm{~L} \mathrm{~m}^{-2} \mathrm{~h}^{-1}$ ). The enhancement of membrane filtration hydraulic performance due to pre-coagulation (with and without settling) has been reported. 2,15,21,28,32-35 This might be due to the formation of a protective cake which prevents some compounds depositing into/onto the membrane or lead to a more porous cake which results in less resistance gain over the filtration cycle as stated elsewhere. ${ }^{21}$ Also, iron salts based coagulants have been noted to remove BPs and humic acids, ${ }^{15,28}$ reducing the foulants load and thus improving the hydraulic membrane performance. Because the coagulant doses used were low, not targeting a DOC decrease, the contribution in this regard may be limited.

The increased attainable filtration flux in winter due to previous micro-coagulation enabled the implementation of similar filtration conditions throughout the year. Doyen et al. ${ }^{34}$ reported similar benefits, as well as the possibility of extending the cleaning frequency, which was also experienced in this work (Table 1). From an engineering standpoint, a design enabling the implementation of the same filtration flux throughout the whole year would be preferred, as well as those conditions maximizing filtration flux since this would require lower membrane surface area.

The performance of micro-coagulation involved the need to undertake a cleaning in place (CIP) with chelating agents (ascorbic and oxalic acids at 1\%wt) in order to remove iron accumulated into/onto the membrane. The CIP was conducted after 3 months of operation, due to an overdose of coagulant, and afterwards it was not needed anymore during the project lifetime.

Even though some previous work experienced an increase in the permeate quality when undertaking a preliminary coagulation step, ${ }^{14,36}$ no significant differences were encountered in this work for most of the parameters monitored, as can be seen in Appendix, Table A1. Nevertheless, the doses applied in the above-mentioned experiments were higher than those used in this study $(<1.5 \mathrm{mg}$ $\mathrm{Fe}(\mathrm{III}) \mathrm{L}^{-1}$ ). Kim et al. ${ }^{37}$ observed that increased removals of TOC and $U_{254}$ occurred above a certain coagulant dose $\left(10 \mathrm{mg} \mathrm{L}^{-1}\right.$ of alum in their study). Other authors reported no increase in UF permeate quality when applying a preliminary coagulation. ${ }^{33}$ In this case, only $\mathrm{SDI}_{15}$ and $\mathrm{MFI}_{0.45}$ presented different (greater) values in the UF permeate when a micro-coagulation was performed, which could be due to the dissolved fraction of Fe(III) able to pass the membrane.

\section{Micro-coagulation effects on UF membrane performance}

The positive effect of conducting a micro-coagulation prior to the UF on the hydraulic conditions was studied from a filtration and a cleaning standpoint, in order to identify the origin of the impact. For such a purpose, 1 month period data was analysed under the four scenarios addressed (summer/winter, coagulation/no coagulation), at $70 \mathrm{~L} \mathrm{~m}^{-2} \mathrm{~h}^{-1}$ filtration flux, except for the winter-no coagulation scenario where the maximum sustainable filtration flux achieved was $40 \mathrm{~L} \mathrm{~m}^{-2} \mathrm{~h}^{-1}$.

\section{Coagulant effect on hydraulic resistance evolution during filtration} cycles

Figure 4 and 5 represent the hydraulic resistance (black symbols), the feed water turbidity (dark grey symbols) and the coagulant dose (pale grey symbols) evolution over time in summer and winter, respectively. CEB performance is indicated as well (open circles) to better understand the membrane behaviour.

As stated previously, the coagulant dose was automatically adjusted according to the system evolution. As can be seen in Fig. 4 and Fig. 5, the coagulant doses required in summer tended to be lower than in winter, which is in agreement with previous observations. ${ }^{38,39}$ This can be due to different reasons, such as coagulant lower hydrolysis degree ${ }^{40}$ and slower kinetics ${ }^{41}$ at colder temperatures, higher TOC content in water during winter ${ }^{39}$ and lower volume fraction of particles in feed water during winter. ${ }^{42}$ $\mathrm{pH}$, which is a key parameter in coagulation, ${ }^{40}$ did not present significant differences between winter and summer, as shown in Table A1. This hampered making any interpretation in terms of coagulation mode in each scenario. However, according to Boulestreau and Miehe, ${ }^{43}$ coagulation $\mathrm{pH}$ had a lower impact on the subsequent membrane permeability than the coagulant dose used.

In summer periods when $\mathrm{Fe}(\mathrm{III})$ dosage was above $1.0 \mathrm{mg} \mathrm{L}^{-1}$ approximately, hydraulic resistance increased faster than at lower doses and $\mathrm{HC}$ efficiency decreased (from 1.0-0.8 to 0.5 approximately, calculated by Equation (1)). Low resistance values could only be recovered by CEBs (Fig. 4). In contrast, in winter time (Fig. 5) the hydraulic resistance increased at a greater rate when 


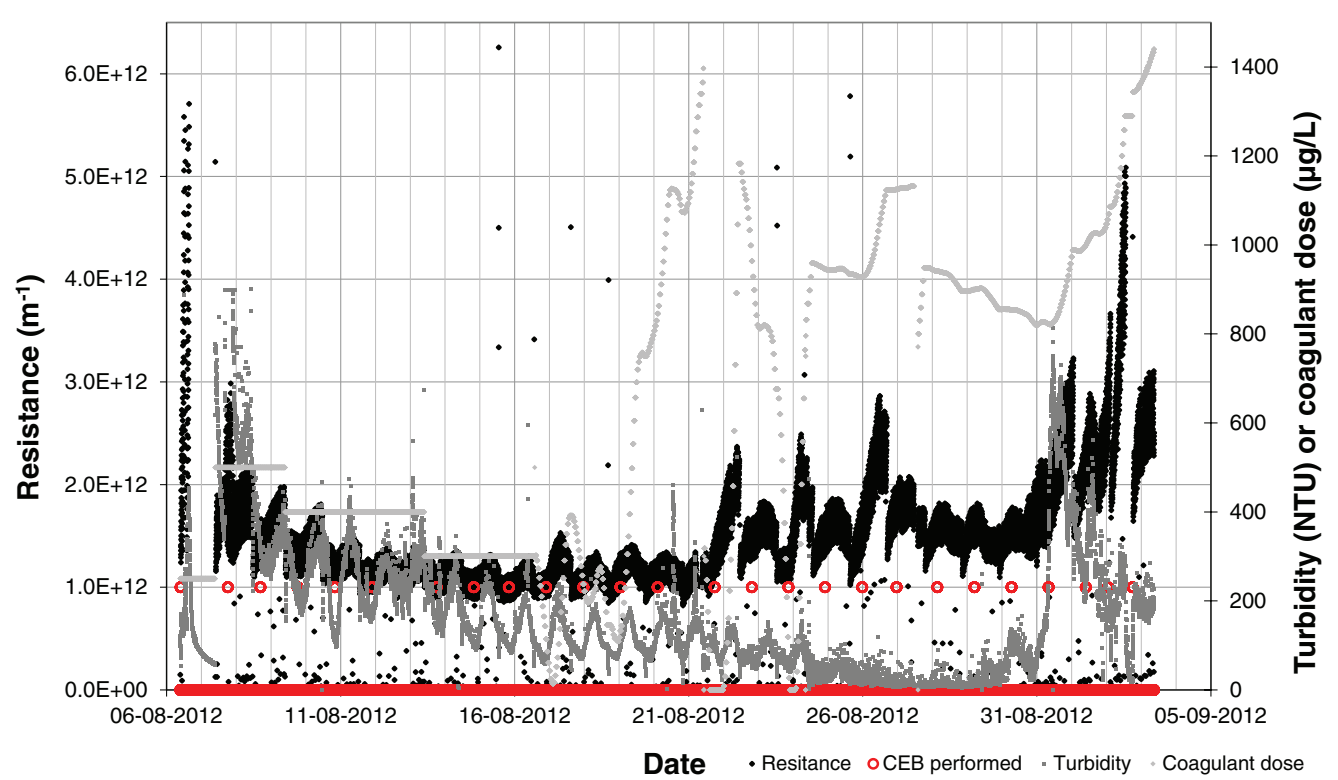

Figure 4. Hydraulic resistance (black symbols), feed water t thebidity (dark grey symbols) and coagulant dose (pale grey symbols) evolution over time in summer conditions. Open circles, arbitrarily marked at $1.0 \mathrm{E}$-12 ${ }^{-1}$, correspond to the moment when a CEB was performed.

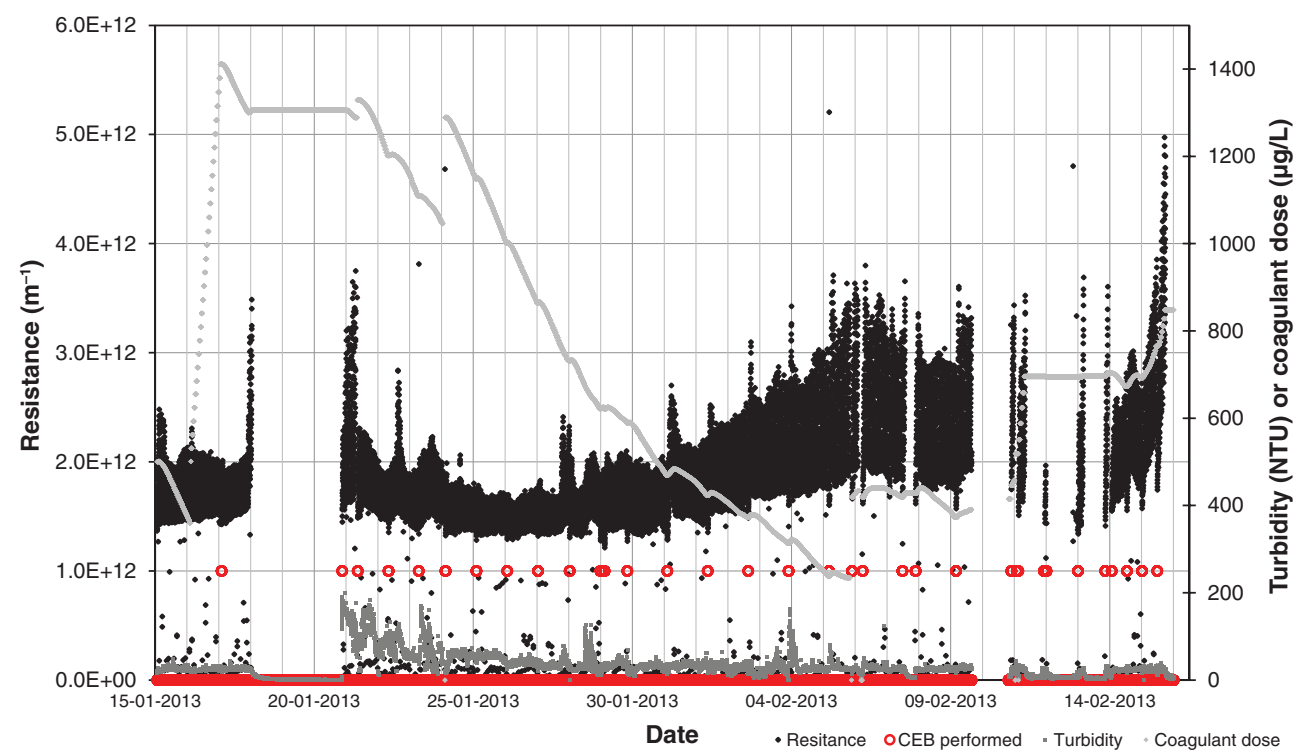

Figure 5. Hydraulic resistance (black symbols), feed water turbidity (dark grey symbols) and coagulant dose (pale grey symbols) evolution over time in winter conditions. Open circles, arbitrarily marked at 1.0E $\mathrm{m} \mathrm{m}^{-1}$, correspond to the moment when a CEB was performed.

doses were below $0.6-0.8 \mathrm{mg} \mathrm{Fe}(\mathrm{III}) \mathrm{L}^{-1}$, presenting an opposite behaviour. In this case, $\mathrm{HC}$ efficiency was slightly decreased but to a much lower extent (from 0.9 to 0.8 approximately, calculated by Equation (1)). Judd and Hillis ${ }^{44}$ suggested that there was a coagulant dose threshold below which detrimental effects occurred: the flocs needed to grow above a certain critical floc size prior to challenging the subsequent membrane stage; otherwise, incomplete aggregation of colloidal particles and precipitated humic materials took place. On the other hand, Boulestreau and Miehe ${ }^{43}$ noted that an excessive coagulant dose had a negative effect on membrane filterability. Finally, Meyn and Leiknes ${ }^{45}$ stated that both overdosing and underdosing coagulant in comparison with its optimal requirements caused increased irreversible fouling. Wang et al. ${ }^{46}$ attributed these effects to incomplete particle aggregation, due to the larger repulsion forces caused by the high charge imbalances.
The small particles and low porosity for compressibility caused a tighter cake layer, deteriorating the permeability. ${ }^{46}$ The existence of an optimal coagulant dose to aid subsequent membrane filtration could explain the discrepancies found in the literature regarding the impact of coagulation on filtration flux, because positive as well as negative effects have been reported. ${ }^{47}$ Wiesner et al. ${ }^{48}$ concluded that those conditions which produced particles with a zeta potential close to zero, which also turned into aggregates size increase, minimized membrane fouling. Therefore, it can be hypothesized that as a first stage the coagulant neutralizes the particle surface charge, generating particles with sizes that form a cake of low hydraulic resistance. Afterwards, further increase in coagulant dose reverses the particle charges, re-stabilizing particles and forming cakes with high hydraulic resistance. $^{43}$ 
The seasonal differences in the raw river water characteristics (e.g. foulants nature and content, physico-chemical properties, coagulant performance), might explain the dissimilarities in membrane performance observed in terms of coagulant need and over/under dosing effects (Fig. 4, Fig. 5). Futselaar et al. ${ }^{49}$ noted the need to continuously adapt the coagulant dose based on the seasonal and long-term trends in water composition, modifications in operational conditions and progressive changes in membrane properties.

Figure 6 shows the hydraulic resistance evolution during each filtration cycle in every scenario considered. Because at the end of each filtration cycle a $\mathrm{HC}$ or a CEB took place, this graph represents the hydraulic resistance evolution from just after a cleaning operation until just before the next cleaning step. In order to assess the variability of the membrane behaviour, all filtration cycles performed during 1 month are depicted, leading to overlapping data. The purpose of the graph is to qualitatively evaluate hydraulic membrane performance evolution during a filtration cycle, to compare the hydraulic membrane behaviour between different filtration cycles and to visualize its variability.

In general, the higher the number of filtration runs (between two consecutive $(\mathrm{CBBs})$, the larger the initial resistance after each $\mathrm{HC}$ (i.e. greater $\mathrm{y}$ axis). This suggested that the $\mathrm{HC}$ was not totally efficient, so that some fouling remained after an $\mathrm{HC}$ was conducted, but it could be partially removed by the subsequent CEB, lowering again the initial resistance. Because a relationship between CEB efficiency and accumulated operational time was not observed, membrane compaction effects might be minimal within these experiments, reinforcing the hypothesis that a non-completely efficient $\mathrm{HC}$ caused the increased initial resistance.

It can also be observed that despite the increased initial resistance in each filtration cycle, in general the resistance evolution was the same for the different filtration cycles in each scenario, not being dependent on the accumulated filtration time (Fig. 6).

When comparing summer/winter scenarios it can be seen that in winter there was a greater resistance increase during the filtration time (Fig. 6 right-hand side graphs vs. left-hand side ones), especially when micro-coagulation was not in place. This was in agreement with the lower flux attainable in a sustainable way during winter time when coagulant was not dosed.

Micro-coagulation reduced the rate of hydraulic resistance increase during each filtration cycle and also stabilized the process (Fig. 6 top graphs vs. bottom ones). These effects were more pronounced in winter than in summer periods, which is also in accordance with the improvement experienced when micro-coagulation was put in place: in winter, attainable flux increased from $40 \mathrm{~L} \mathrm{~m}^{-2} \mathrm{~h}^{-1}$ to $70 \mathrm{~L} \mathrm{~m}^{-2} \mathrm{~h}^{-1}$ (Table 1). Microcoagulation had a positive effect on $\mathrm{HC}$ efficiency in both seasons, because the initial resistance in each filtration run (y axis) did not increase as much as when micro-coagulation was not in place.

In order to isolate the coagulant effect on cleaning efficiency and only focus on its effect during filtration, specific cake resistance was calculated by means of Equation (3) (Table 2). As described later on, cake filtration was identified as the main fouling mechanism in all the scenarios addressed. The specific cake resistance was calculated, which indicated the increase of foulants cake layer resistance build up in each case. As depicted, the hydraulic resistance increase rate was higher in winter than in summer, which is in agreement with the hydraulic conditions attainable previously described. It was particularly high in the no coagulation-winter
Table 2. Specific cake resistance statistics under the four conditions considered (coagulation/no coagulation, summer/winter)

\begin{tabular}{lrrrc|}
$\alpha\left(\mathrm{m}^{-2}\right)$ & Minimum & Maximum & Average & St. deviation \\
\hline No coag - Summer & $5.0 \mathrm{E}^{+12}$ & $1.8 \mathrm{E}^{+15}$ & $1.8 \mathrm{E}^{+13}$ & $5.0 \mathrm{E}^{+13}$ \\
No coag - Winter & $5.7 \mathrm{E}^{+11}$ & $2.4 \mathrm{E}^{+16}$ & $7.5 \mathrm{E}^{+13}$ & $1.1 \mathrm{E}^{+15}$ \\
$\mathrm{FeCl}_{3}$ - Summer & $3.6 \mathrm{E}^{+12}$ & $1.0 \mathrm{E}^{+14}$ & $7.5 \mathrm{E}^{+12}$ & $4.8 \mathrm{E}^{+12}$ \\
$\mathrm{FeCl}_{3}$ - Winter & $5.7 \mathrm{E}^{+12}$ & $4.5 \mathrm{E}^{+12}$ & $1.3 \mathrm{E}^{+13}$ & $6.0 \mathrm{E}^{+12}$ \\
\hline
\end{tabular}

scenario. In this case, the average specific cake resistance was around 6-fold greater than in the coagulation-winter condition and presented a much larger deviation (180-fold approximately). Therefore, the dosage of ferric chloride significantly stabilized the filtration process in winter. This was in agreement with the more demanding conditions in terms of filtration flux the membrane could handle. In summer, the average specific cake resistance was lowered 2.5-fold approximately and its associated standard deviation 10 times when micro-coagulation was conducted.

Literature has reported cake filtration as the main fouling mechanism when in-line coagulation has been applied, eliminating pore blockage. ${ }^{2}$ However, some work has also determined cake formation as the dominant fouling mode for untreated feed water. ${ }^{50}$ In order to determine whether a different fouling mechanism prevailed in winter/summer, coagulation/no-coagulation conditions, the experimental data obtained was fitted to the traditional blocking laws models (complete blocking, standard blocking, intermediate pore blocking and cake filtration) for constant flow filtration..$^{51,52}$ Transmembrane pressure (TMP) ${ }^{-1}$ vs filtered volume (V), (TMP) $)^{-0.5}$ vs V, $\ln (T M P)$ vs (V) and TMP vs V, were plotted, representing the above-mentioned blocking laws, respectively, for each scenario. In all cases, cake filtration seemed to be the mechanism which better described the experimental data according to the regression coefficients $\left(R^{2}\right)$ obtained. However, it is important to mention that regression coefficients obtained per blocking mechanism did not differ between them to a large extent. This could partially be due to the working pressure range, between 0.09 and 0.53 bar for the considered periods, which made most of the models fit quite well $\left(R^{2}: 0.91-0.98\right)$. Experiments performed under constant filtration flow successfully identified the main fouling mechanism by fitting the different models to the experimental data and that reported in the literature ${ }^{51}$ which used a wider pressure range. They were conducted at bench scale, and thus, hydraulic conditions could be forced. In this study, the hydraulic operational conditions required by the full scale system were limited (TMP $<1$ bar, hydraulic resistance $<1.0 \mathrm{E}^{+13} \mathrm{~m}^{-1}$ ). Additionally, the discrepancies between the process conditions and the model assumptions, as well as the existence of several mechanisms occurring simultaneously, might make a better fitting difficult.

Assuming the set up limitations and based on the regression coefficients obtained, cake filtration could be suggested as the prevailing blocking mechanism in all scenarios. Then, blocking laws would not explain the membrane hydraulic differences experienced in summer/winter, coagulation/non-coagulation. Consequently, it might be the fouling cake characteristics which caused the different membrane filtration behaviours experienced. This would be in accordance with Jermann et $a l^{53}$, who stated that the flux decline was determined by the morphology of the fouling cake, whereas fouling reversibility was determined by the interaction between the cake layer and the membrane surface. 

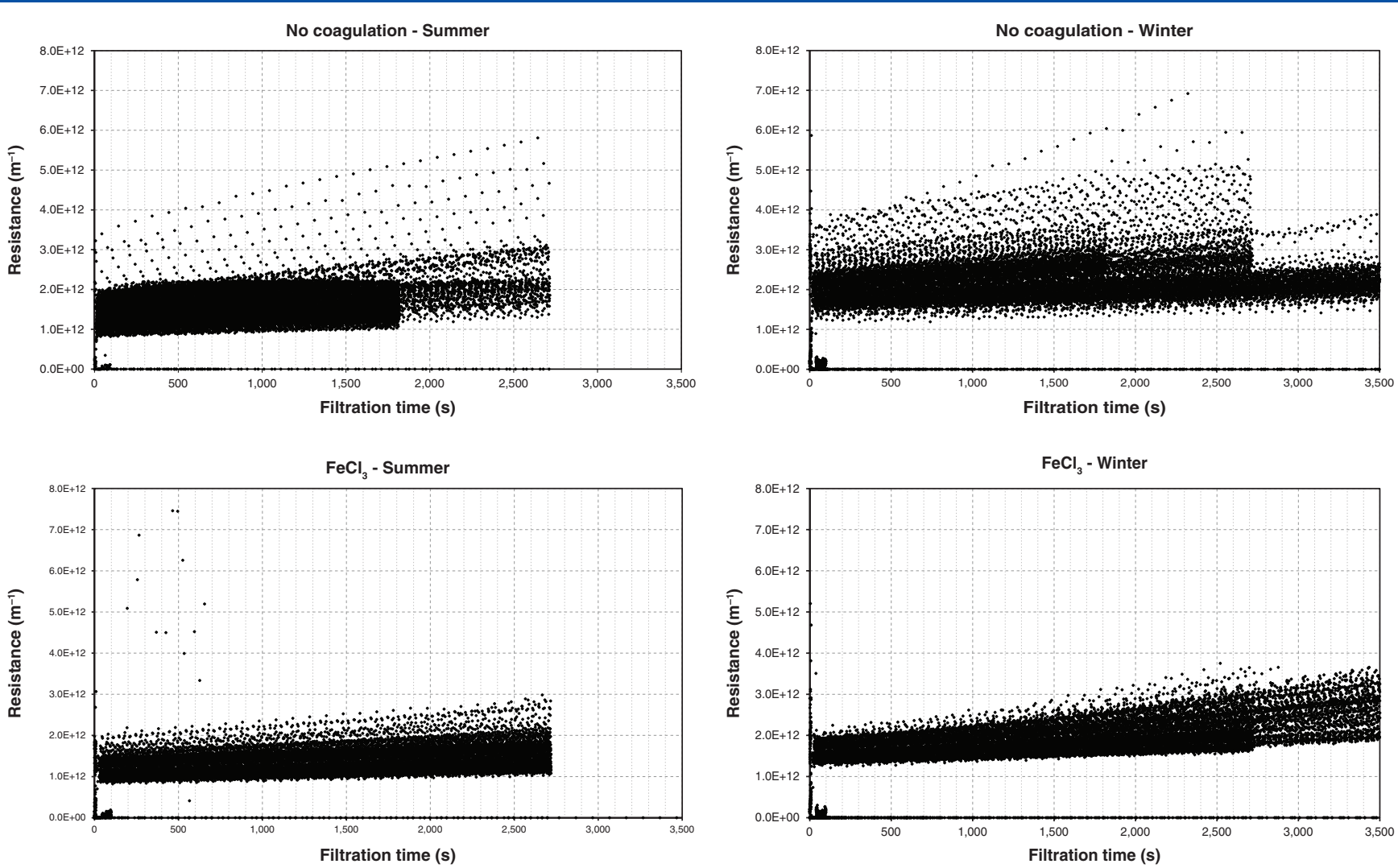

Figure 6. Hydraulic resistance evolution over time during each filtration cycle for 1 month under the following conditions: top left-hand side - summer no coagulation; top right-hand side - winter no coagulation; bottom left-hand side - summer coagulation; bottom right-hand side - winter coagulation.

Previous work observed that cake porosity was much higher when coagulation was in place $(93 \%$ vs. $37 \%){ }^{34}$ which could explain the performance observed. More porous cakes have been related to lower TMP increases ${ }^{34}$ since they present diminished resistance. ${ }^{26}$ Similarly, less compressible cakes have been claimed to have the same effect: ${ }^{31}$ Heijman et al. ${ }^{54}$ reported a 2-fold decrease in compressibility due to coagulation.

\section{Coagulant effect on hydraulic resistance recovery by HC and CEB} $\mathrm{HC}$ cleaning efficiency in the four scenarios envisaged was calculated by means of Equation (1) and its associated statistics are shown in Table 3.

As can be seen in Table 3, in average terms, the $\mathrm{HC}$ was more effective in winter than in summer regardless of coagulant dosage (significance 0.05). Taking into account that the HC sequence and conditions were not modified during the whole study, it can be concluded that in winter, either less foulants were accumulated between $\mathrm{HCs}$, resulting in a more efficient $\mathrm{HC}$, or foulants were more easily removed by the HCs. In this regard, BPs, by virtue of their high $\mathrm{MW}$ and size, are mostly retained by cake formation, and thus, amenable to being washed out by $\mathrm{HCs}^{55}$ BPs concentration in raw river water was higher in winter, which would be in accordance with the greater $\mathrm{HC}$ efficiency experienced. On the other hand, raw water physico-chemical characteristics (Table A1) showed greater turbidity and TSS content in summer, which would support the hypothesis of higher foulants load accumulated in summer periods.

Micro-coagulation resulted in a significant increase in $\mathrm{HC}$ efficiency, both in summer and in winter ( 5 and $15 \%$ respectively; 0.05 significance), which is in accordance with Zupančič et al. ${ }^{56}$ as well as a decrease in its variability. In this study, probably the coagulant dosage enabled the formation of a cake which acted like a filter aid, preventing molecules with high fouling potential reaching the membrane. This probably led to a cake more easily removed by physical means.

Table 3 also presents the CEB efficiency for the four scenarios considered, calculated using Equation (2). Unlike the HC efficiency, the average CEB efficiency in winter was significantly below that in summer. This was expected, because in order to increase chemical cleaning efficiency, heating is an option commonly adopted, and in summer water temperature was higher than in winter (26.5 vs $8.9^{\circ} \mathrm{C}$ on average). This could be attributed to augmented kinetics of the reaction between foulants and cleaning agents, their increased solubility and/or the greater diffusion and reaction rates at higher temperatures. Also, the chemical nature of the fouling itself according to the season might have an impact, being more physically irreversible in summer, and thus, leading to a lower $\mathrm{HC}$ efficiency in those conditions, but presenting greater CEB efficiency. When comparing coagulation/non-coagulation, it can be seen that in winter there was an increase in efficiency ( 0.36 vs. 0.42$)$ and a slight stabilization of the variability ( 0.05 vs. 0.040$)$, whereas in summer there was a decrease in efficiency ( $0.61 \mathrm{vs.} 0.57)$ and in variability $(0.07$ vs. 0.10$)$. In this case the coagulant performance might also contribute to the different trends observed.

\section{CONCLUSIONS}

Direct UF of raw river water proved to be a technically feasible and competitive alternative to the conventional DWTP pre-treatment 


\begin{tabular}{|c|c|c|c|c|c|}
\hline Cleaning operation & Scenario & Minimum & Maximum & Average & St. deviation \\
\hline \multirow[t]{4}{*}{$\eta_{\mathrm{HC}}$} & No coag - Summer & 0.45 & 1.14 & 0.74 & 0.13 \\
\hline & No coag - Winter & 0.57 & 1.14 & 0.87 & 0.09 \\
\hline & $\mathrm{FeCl}_{3}$ - Summer & 0.45 & 1.12 & 0.86 & 0.11 \\
\hline & $\mathrm{FeCl}_{3}$ - Winter & 0.57 & 1.50 & 0.92 & 0.07 \\
\hline \multirow[t]{4}{*}{$\eta_{\mathrm{CEB}}$} & No coag - Summer & 0.48 & 0.73 & 0.61 & 0.07 \\
\hline & No coag - Winter & 0.26 & 0.48 & 0.36 & 0.05 \\
\hline & $\mathrm{FeCl}_{3}$ - Summer & 0.36 & 0.73 & 0.57 & 0.10 \\
\hline & $\mathrm{FeCl}_{3}$ - Winter & 0.34 & 0.49 & 0.42 & 0.04 \\
\hline
\end{tabular}

process (dioxichlorination, coagulation, flocculation/settling and sand filtration), enabling continuous operation regardless of incoming water quality fluctuations (e.g. turbidity 5 to $>1000$ NTU) and to deliver a product water of equal or superior quality to the current one for most of the parameters monitored. Despite the challenging position of the UF membrane (raw river water direct filtration) no integrity problems were encountered during the 2 years evaluated.

Hydraulic membrane performance differed between seasons, achieving higher filtration fluxes in summer. This could be due to the membrane properties as well as the feed physico-chemical water characteristics, especially in terms of foulants nature and content. DOC concentration was higher in winter periods, with greater BPs and low molecular weight substances content, which have been claimed to be main membrane foulants and cause high specific cake resistance, respectively.

Based on the greater HC efficiency experienced, foulants in winter tended to form a looser cake or lower amounts were accumulated. However, the cake presented higher resistance, leading to larger hydraulic resistance increase during filtration. Hence, it can be hypothesized that in summer a more porous cake was formed, which caused a lower pressure drop, but it was more tightly bound to the membrane, provoking lower $\mathrm{HC}$ efficiency. Alternatively, larger amounts of foulants were accumulated into/onto the membrane, which could also provoke diminished HC efficiency.

Performing a ferric chloride micro-coagulation upstream the UF membrane in winter enabled a significant increase in tolerable conditions. As a result, the seasonal variations in attainable filtration fluxes were decreased, enabling the implementation of similar conditions in summer and in winter. Micro-coagulation also reduced by half the chemically based cleaning operations frequency in all the conditions addressed.

In winter, the benefits of micro-coagulation were mainly in the filtration stage, since specific cake resistance was lowered around 6-fold and was significantly stabilized (standard deviation decreased by 180 times approximately) when it was applied. Again, this could be due to the formation of a more porous cake, leading to lower hydraulic resistance gain over each filtration cycle. HC and CEB cleaning efficiencies were also improved, but to a lesser extent. In summer periods, micro-coagulation also affected positively the filtration stage, reducing by a factor of 2.5 approximately the specific cake resistance and stabilizing it, and slightly increasing the $\mathrm{HC}$ and decreasing the CEB efficiencies. Larger coagulant doses were needed to build up cakes with the desired characteristics (high permeability and strength according to Pikkarainen et al. ${ }^{38}$ ) in winter compared with summer, under-dosing being more detrimental in winter and overdosing in summer.

\section{ACKNOWLEDGEMENTS}

This work was conducted under the financial support of the LIFE+ Programme of the European Commission within the framework of the UFTEC Project (LIFE09 ENV/ES/000467 UFTEC). Carmen Galvañ and Albert Bobé (CETaqua), Marc Pons and Sandra Cruz (Aigües de Barcelona) and Tom Spanjer and Sergi Lluch (Pentair X-Flow) are thanked for their contributions. 


\section{APPENDIX}

Table A1 Physico-chemical and micro-biological results obtained of the raw river and the direct UF permeate in the four scenarios considered, as well as from conventionally pre-treated water (dioxichlorination, coagulation/flocculation, settling and sand filtration) for summer and winter periods. MPN: most probable number; CFU: colony forming unit; LoQ: limit of quantification

\begin{tabular}{|c|c|c|c|c|c|c|c|}
\hline Scenario & Parameter & Units & Sampling point & Minimum & Maximum & Average & St. deviation \\
\hline \multirow[t]{26}{*}{ No coag - Summer } & Turbidity & NTU & Feed & 35.4 & 186.0 & 63.9 & 32.9 \\
\hline & & & Permeate & 0.038 & 0.148 & 0.068 & 0.027 \\
\hline & TSS & $\mathrm{mg} \mathrm{L}^{-1}$ & Feed & $<$ LoQ & 232.0 & 76.8 & 58.0 \\
\hline & & & Permeate & $<$ LoQ & 1.75 & 1.05 & 0.65 \\
\hline & Temperature & ${ }^{\circ} \mathrm{C}$ & Feed & 20.8 & 30.4 & 26.4 & 1.9 \\
\hline & $\mathrm{pH}$ & & Feed & 6.99 & 8.80 & 8.09 & 0.40 \\
\hline & DOC & $\mathrm{mgCL} \mathrm{L}^{-1}$ & Feed & 3.27 & 6.42 & 4.72 & 1.15 \\
\hline & & & Permeate & 3.19 & 6.51 & 4.11 & 1.37 \\
\hline & $\mathrm{UV}_{254}$ & $\mathrm{~cm}^{-1}$ & Feed & 0.076 & 0.158 & 0.095 & 0.018 \\
\hline & & & Permeate & 0.070 & 0.141 & 0.084 & 0.017 \\
\hline & SUVA & $\mathrm{Lcm}^{-1} \mathrm{mg}^{-1}$ & Feed & 1.51 & 2.68 & 2.27 & 0.40 \\
\hline & & & Permeate & 2.17 & 2.96 & 2.35 & 0.34 \\
\hline & $\mathrm{SDI}_{15}$ & $\% \min ^{-1}$ & Feed & $>6$ & $>6$ & $>6$ & N.A. \\
\hline & & & Permeate & 1.67 & 2.63 & 2.17 & 0.28 \\
\hline & $\mathrm{MFI}_{0.45}$ & $\mathrm{Ls}^{-2}$ & Feed & 898.0 & 5737.0 & 2686.3 & 2242.0 \\
\hline & & & Permeate & 0.22 & 0.41 & 0.30 & 0.06 \\
\hline & $\log _{10}$ (total coliforms) & $\begin{array}{l}\log _{10}(\text { MPN per } \\
\quad 100 \mathrm{~mL})\end{array}$ & Feed & 3.89 & 5.86 & 4.56 & 0.77 \\
\hline & & & Permeate & absence & absence & absence & N.A. \\
\hline & $\log _{10}$ (faecal coliforms) & $\begin{array}{l}\log _{10}(\mathrm{MPN} \text { per } \\
100 \mathrm{~mL})\end{array}$ & Feed & 2.76 & 5.38 & 3.64 & 1.02 \\
\hline & & & Permeate & absence & absence & absence & N.A. \\
\hline & $\log _{10}($ E. coli $)$ & $\begin{array}{l}\log _{10}(\text { MPN per } \\
\quad 100 \mathrm{~mL})\end{array}$ & Feed & 2.46 & 5.20 & 3.33 & 1.10 \\
\hline & & & Permeate & absence & absence & absence & N.A. \\
\hline & $\begin{array}{l}\log _{10} \text { (Clostridium } \\
\text { perfringens) }\end{array}$ & $\begin{array}{l}\log _{10} \text { (CFU per } \\
\quad 100 \mathrm{~mL})\end{array}$ & Feed & 3.11 & 4.20 & 3.47 & 0.48 \\
\hline & & & Permeate & absence & absence & absence & N.A. \\
\hline & $\begin{array}{l}\log _{10} \text { (aerobic bacteria at } \\
22^{\circ} \mathrm{C} \text { ) }\end{array}$ & $\begin{array}{l}\log _{10} \text { (CFU per } \\
\mathrm{mL})\end{array}$ & Feed & 3.85 & 4.95 & 4.27 & 0.51 \\
\hline & & & Permeate & 0.30 & 5.65 & 2.83 & 2.20 \\
\hline \multirow[t]{21}{*}{ No coag - Winter } & Turbidity & NTU & Feed & 4.6 & 53.0 & 24.3 & 15.4 \\
\hline & & & Permeate & 0.052 & 0.097 & 0.074 & 0.014 \\
\hline & TSS & $\mathrm{mg} \mathrm{L}^{-1}$ & Feed & 4.0 & 51.5 & 24.4 & 16.8 \\
\hline & & & Permeate & $<$ LoQ & 1.00 & 0.31 & 0.47 \\
\hline & Temperature & ${ }^{\circ} \mathrm{C}$ & Feed & 4.8 & 14.0 & 9.2 & 2.1 \\
\hline & $\mathrm{pH}$ & & Feed & 6.59 & 8.93 & 8.15 & 0.28 \\
\hline & DOC & $\mathrm{mgCL}^{-1}$ & Feed & 3.36 & 12.13 & 7.53 & 4.40 \\
\hline & & & Permeate & 2.81 & 3.09 & 2.98 & 0.15 \\
\hline & $\mathrm{UV}_{254}$ & $\mathrm{~cm}^{-1}$ & Feed & 0.074 & 0.373 & 0.111 & 0.077 \\
\hline & & & Permeate & 0.068 & 0.097 & 0.076 & 0.007 \\
\hline & SUVA & $\mathrm{L} \mathrm{cm}^{-1} \mathrm{mg}^{-1}$ & Feed & 0.91 & 2.41 & 1.47 & 0.82 \\
\hline & & & Permeate & 2.22 & 2.79 & 2.48 & 0.28 \\
\hline & $\mathrm{SDI}_{15}$ & $\% \min ^{-1}$ & Feed & $>6$ & $>6$ & $>6$ & N.A. \\
\hline & & & Permeate & 0.91 & 2.44 & 1.87 & 0.56 \\
\hline & $\mathrm{MFI}_{0.45}$ & $\mathrm{Ls}^{-2}$ & Feed & 87.1 & 589.3 & 415.9 & 284.9 \\
\hline & & & Permeate & 0.07 & 0.26 & 0.17 & 0.07 \\
\hline & $\log _{10}$ (total coliforms) & $\begin{array}{l}\log _{10}(\mathrm{MPN} \text { per } \\
100 \mathrm{~mL})\end{array}$ & Feed & 4.18 & 4.84 & 4.47 & 0.34 \\
\hline & & & Permeate & absence & absence & absence & N.A. \\
\hline & $\log _{10}$ (faecal coliforms) & $\begin{array}{l}\log _{10}(\text { MPN per } \\
100 \mathrm{~mL})\end{array}$ & Feed & 3.94 & 4.30 & 4.13 & 0.18 \\
\hline & & & Permeate & absence & absence & absence & N.A. \\
\hline & $\log _{10}($ E. coli $)$ & $\begin{array}{l}\log _{10}(\mathrm{MPN} \text { per } \\
100 \mathrm{~mL})\end{array}$ & Feed & 3.23 & 3.52 & 3.35 & 0.15 \\
\hline
\end{tabular}




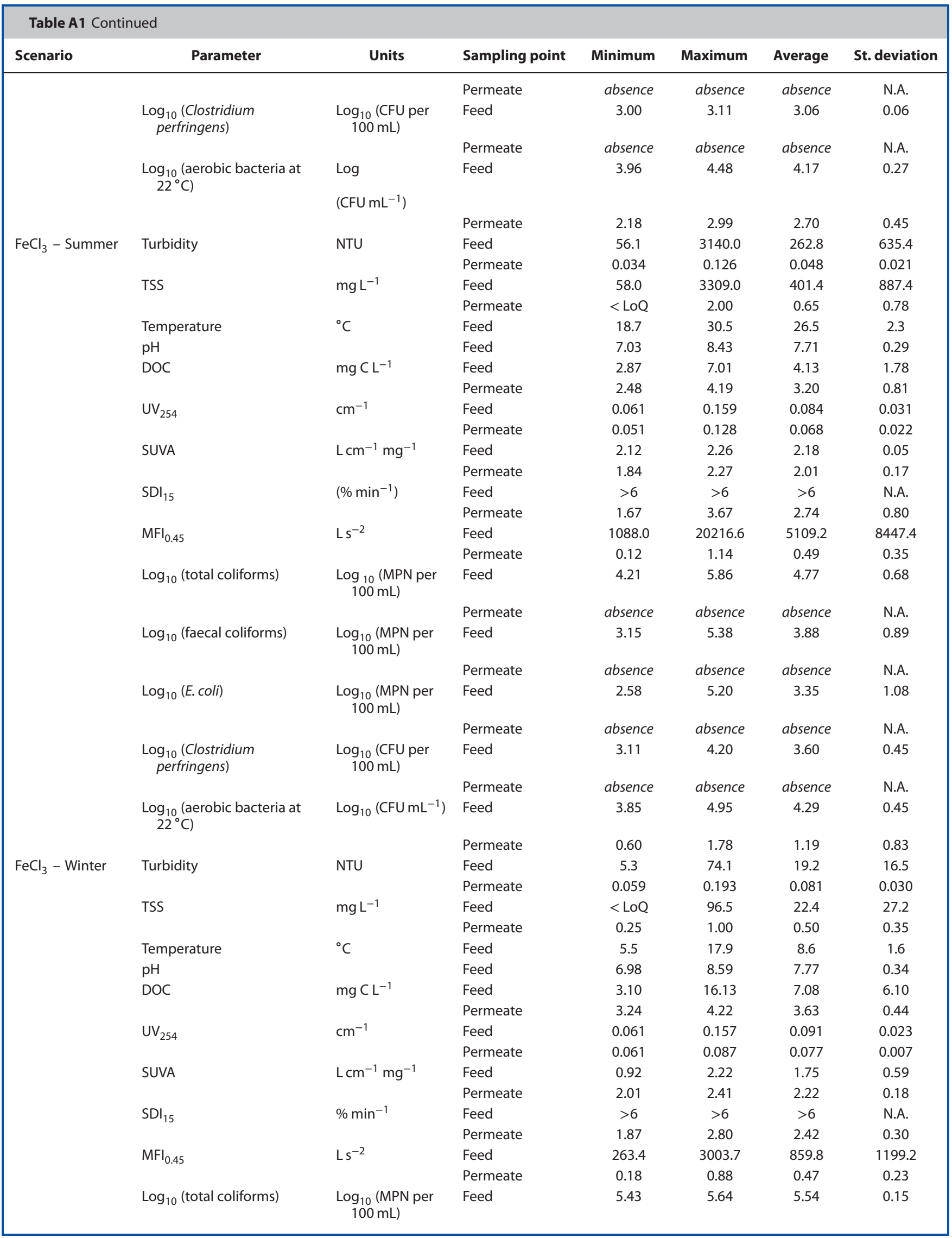




\begin{tabular}{|c|c|c|c|c|c|c|c|}
\hline Scenario & Parameter & Units & Sampling point & Minimum & Maximum & Average & St. deviation \\
\hline & & & Permeate & absence & absence & absence & N.A. \\
\hline & $\log _{10}$ (faecal coliforms) & $\begin{array}{l}\log _{10}(\mathrm{MPN} \text { per } \\
100 \mathrm{~mL})\end{array}$ & Feed & 5.04 & 5.30 & 5.17 & 0.18 \\
\hline & & & Permeate & absence & absence & absence & N.A. \\
\hline & $\log _{10}($ E. coli $)$ & $\begin{array}{l}\log _{10} \text { (MPN per } \\
100 \mathrm{~mL})\end{array}$ & Feed & 4.38 & 5.04 & 4.71 & 0.47 \\
\hline & & & Permeate & absence & absence & absence & N.A. \\
\hline & $\begin{array}{l}\log _{10} \text { (Clostridium } \\
\text { perfringens) }\end{array}$ & $\begin{array}{l}\log _{10} \text { (CFU per } \\
100 \mathrm{~mL})\end{array}$ & Feed & 4.08 & 4.08 & 4.08 & N.A. \\
\hline & & & Permeate & absence & absence & absence & N.A. \\
\hline & $\begin{array}{l}\log _{10} \text { (aerobic bacteria at } \\
22^{\circ} \mathrm{C} \text { ) }\end{array}$ & $\log _{10}(\mathrm{CFU} \mathrm{mL}-1)$ & Feed & 4.94 & 4.94 & 4.94 & N.A. \\
\hline & & & Permeate & 1.18 & 1.18 & 1.18 & N.A. \\
\hline \multirow{14}{*}{$\begin{array}{l}\text { Sand } \\
\quad \text { filters - Winter }\end{array}$} & Turbidity & NTU & Permeate & 0.198 & 0.469 & 0.321 & 0.086 \\
\hline & TSS & $\mathrm{mg} \mathrm{L}^{-1}$ & Permeate & $<$ LoQ & 1.50 & 0.50 & 0.87 \\
\hline & Temperature & ${ }^{\circ} \mathrm{C}$ & Permeate & 5.7 & 16.8 & 9.4 & 4.0 \\
\hline & $\mathrm{pH}$ & & Permeate & 7.75 & 8.86 & 8.30 & 0.38 \\
\hline & DOC & $\mathrm{mgCL} \mathrm{L}^{-1}$ & Permeate & 2.85 & 6.24 & 4.55 & 2.39 \\
\hline & $U_{254}$ & $\mathrm{~cm}^{-1}$ & Permeate & 0.058 & 0.076 & 0.065 & 0.0056 \\
\hline & SUVA & $\mathrm{L} \mathrm{cm}^{-1} \mathrm{mg}^{-1}$ & Permeate & 0.98 & 2.38 & 1.68 & 0.99 \\
\hline & $\mathrm{SDI}_{15}$ & $\% \min ^{-1}$ & Permeate & 4.52 & 5.42 & 4.98 & 0.34 \\
\hline & $\mathrm{MFI}_{0.45}$ & $\mathrm{Ls}^{-2}$ & Permeate & 3.80 & 23.93 & 8.69 & 8.59 \\
\hline & $\log _{10}$ (total coliforms) & $\begin{array}{l}\log _{10}(\mathrm{MPN} \\
100 \mathrm{~mL})\end{array}$ & Permeate & 0.48 & 1.43 & 0.75 & 0.46 \\
\hline & $\log _{10}$ (faecal coliforms) & $\begin{array}{l}\log _{10} \text { (MPN per } \\
\quad 100 \mathrm{~mL})\end{array}$ & Permeate & absence & 0.60 & 0.30 & 0.43 \\
\hline & $\log _{10}($ E. coli $)$ & $\begin{array}{l}\log _{10} \text { (MPN per } \\
\quad 100 \mathrm{~mL})\end{array}$ & Permeate & absence & 0.60 & 0.30 & 0.43 \\
\hline & $\begin{array}{l}\log _{10} \text { (Clostridium } \\
\text { perfringens) }\end{array}$ & $\begin{array}{l}\log _{10} \text { (CFU per } \\
100 \mathrm{~mL})\end{array}$ & Permeate & 0.60 & 1.08 & 0.90 & 0.21 \\
\hline & $\begin{array}{l}\log _{10} \text { (aerobic bacteria at } \\
22^{\circ} \mathrm{C} \text { ) }\end{array}$ & $\log _{10}\left(\mathrm{CFU} \mathrm{mL} \mathrm{mL}^{-1}\right)$ & Permeate & 2.08 & 2.76 & 2.46 & 0.30 \\
\hline \multirow{14}{*}{$\begin{array}{l}\text { Sand fil- } \\
\quad \text { ters - Summer }\end{array}$} & Turbidity & NTU & Permeate & 0.129 & 0.435 & 0.254 & 0.111 \\
\hline & TSS & $\mathrm{mg} \mathrm{L}^{-1}$ & Permeate & 1.25 & 2.00 & 1.65 & 0.285 \\
\hline & Temperature & ${ }^{\circ} \mathrm{C}$ & Permeate & 22.5 & 29.4 & 25.9 & 2.6 \\
\hline & $\mathrm{pH}$ & & Permeate & 7.88 & 8.75 & 8.32 & 0.33 \\
\hline & DOC & $\mathrm{mg} \mathrm{CL^{-1 }}$ & Permeate & 2.65 & 3.86 & 3.38 & 0.502 \\
\hline & $\mathrm{UV}_{254}$ & $\mathrm{~cm}^{-1}$ & Permeate & 0.053 & 0.080 & 0.067 & 0.009 \\
\hline & SUVA & $\mathrm{Lcm}^{-1} \mathrm{mg}^{-1}$ & Permeate & 1.97 & 2.28 & 2.13 & 0.13 \\
\hline & $\mathrm{SDI}_{15}$ & $\% \min ^{-1}$ & Permeate & 4.97 & 6.21 & 5.56 & 0.45 \\
\hline & $\mathrm{MFI}_{0.45}$ & $\mathrm{Ls}^{-2}$ & Permeate & 4.07 & 41.70 & 10.89 & 11.00 \\
\hline & $\log _{10}$ (total coliforms) & $\begin{array}{l}\log _{10}(\mathrm{MPN} \text { per } \\
100 \mathrm{~mL})\end{array}$ & Permeate & 3.99 & 6.41 & 5.01 & 1.01 \\
\hline & $\log _{10}$ (faecal coliforms) & $\begin{array}{l}\log _{10}(\mathrm{MPN} \text { per } \\
100 \mathrm{~mL})\end{array}$ & Permeate & absence & 2.20 & 0.72 & 1.02 \\
\hline & $\log _{10}($ E. coli $)$ & $\begin{array}{l}\log _{10} \text { (MPN per } \\
\quad 100 \mathrm{~mL})\end{array}$ & Permeate & absence & 2.08 & 0.77 & 0.87 \\
\hline & $\begin{array}{l}\log _{10} \text { (Clostridium } \\
\text { perfringens) }\end{array}$ & $\begin{array}{l}\log _{10} \text { (CFU per } \\
\quad 100 \mathrm{~mL})\end{array}$ & Permeate & absence & 1.79 & 0.50 & 0.78 \\
\hline & $\begin{array}{l}\log _{10} \text { (aerobic bacteria at } \\
22^{\circ} \mathrm{C} \text { ) }\end{array}$ & $\log _{10}\left(\mathrm{CFU} \mathrm{mL} \mathrm{L}^{-1}\right)$ & Permeate & 2.66 & 3.96 & 4.49 & 0.60 \\
\hline
\end{tabular}




\section{REFERENCES}

1 UNESCO. World Water Development Report 3: Water in a Changing World. London (2009).

2 Huang H, Schwab K and Jacangelo JG, Critical review pretreatment for low pressure membranes in water treatment: a review. Environ Sci Technol 43:3011 - 3029 (2009).

3 Clever M, Jordt F, Knauf R, Räbiger N, Rüdebusch M and Hilker-Scheibel $\mathrm{R}$, Process water production from river water by ultrafiltration and reverse osmosis. Desalination 131:325-336 (2000).

4 Hofman JAMH, Beumer MM, Baars ET, van der Hoek JP and Koppers HMM, Enhanced surface water treatment by ultrafiltration. Desalination 119: 113-125 (1998).

$5 \mathrm{Li} \mathrm{W}$ and Dong B, Characteristic of ultrafiltration on treatment surface-water in China. 2nd International Conference on Bioinformation Biomedical Engineering, iCBBE 2008, 3640-3644 (2008).

6 Rojas JC, Moreno B, Garralón G, Plaza F, Pérez J and Gómez Ma, Potabilization of low NOM reservoir water by ultrafiltration spiral wound membranes. J Hazard Mater 158:593-598 (2008).

7 Vos G, Brekvoort Y, Oosterom H a and Nederlof MMTreatment of canal water with ultrafiltration to produce industrial and household water. Desalination 118:297-303 (1998).

8 Pearce GK, The case for UF/MF pretreatment to RO in seawater applications. Desalination 203:286-295 (2007).

9 Pianta R, Boller M, Janex ML, Chappaz A, Birou B, Ponce R, et al., Microand ultrafiltration of karstic spring water. Desalination 117:61-71 (1998).

10 Oosterom H, Galjaard G, Nederlof MM and Schippers JC, Feasibility of micro- and ultrafiltration for the direct treatment of surface water: results of various pilot studies. Desalination 1998;119:275-276 (1998).

11 Schlichter B, Mavrov V and Chmiel H, Study of a hybrid process combining ozonation and microfiltration/ultrafiltration for drinking water production from surface water. Process Technol 168:307-317 (2004).

12 Pearce GK, UF/MF pre-treatment to RO in seawater and wastewater reuse applications: a comparison of energy costs. Desalination 222:66-73 (2008)

13 Fiksdal $L$ and Leiknes $T$, The effect of coagulation with MF/UF membrane filtration for the removal of virus in drinking water. $J$ Membr Sci 279:364-371 (2006)

14 Konieczny K, Sakol D and Bodzek M, Efficiency of the hybrid coagulation-ultrafiltration water treatment process with the use of immersed hollow-fiber membranes. Desalination 198:102-110 (2006).

15 Zheng $X$, Plume S, Ernst $M$, Croué JP and Jekel $M$, In-line coagulation prior to UF of treated domestic wastewater - foulants removal, fouling control and phosphorus removal. J Membr Sci 403-404:129-139 (2012).

16 Howe KJ, Marwah A, Chiu K-P and Adham SS, Effect of coagulation on the size of MF and UF membrane foulants. Environ Sci Technol 40:7908-7913 (2006)

17 Zheng D, Andrews RC, Andrews SA. and Taylor-Edmonds L, Effects of coagulation on the removal of natural organic matter, genotoxicity, and precursors to halogenated furanones. Water Res 70:118-129 (2015).

18 Ferrer O, Serrallach X, Horváth F, Mesa J, Gibert O and Bernat X, Pre-treatment of Llobregat River raw water through pressurised inside/out hollow fibre ultrafiltration membranes. Desalin Water Treat 51:1831-1837 (2013).

19 Hutzinger $\mathrm{O}$, The Llobregat: the story of a polluted mediterranean river, in The Handbook of Environmental Chemistry, ed by Sabater S, Ginebreda A and Barceló D. Springer-Velag, Berlin/Heidelberg (2012).

20 Edzwald JK, Water Quality and Treatment: A Handbook on Drinking Water, 6th edn. American Water Works Association, American Society of Civil Engineers, McGraw-Hill (2011).

21 Blankert B, Betlem BHL and Roffel B, Development of a control system for in-line coagulation in an ultrafiltration process. J Membr SCi 301:39-45 (2007).

22 Huber SA, Balz A, Abert M and Pronk W, Characterisation of aquatic humic and non-humic matter with size-exclusion chromatography - organic carbon detection - organic nitrogen detection (LC-OCD-OND). Water Res 45:879-885 (2011).

23 Chen W, Westerhoff P, Leenheer JA and Booksh K, Fluorescence excitation-emission matrix regional integration to quantify spectra for dissolved organic matter. Environ Sci Technol 37:5701-5710 (2003).

24 Ferrer O, Casas R, Galvañ C, Lucena F, Vega A, Gibert O et al., Challenge tests with virus surrogates: an accurate membrane integrity evaluation system? Desalin Water Treat 51:4947-4957 (2013).

25 Ma C, Wang L, Li S, Heijman SGJ, Rietveld LC and Su XB, Practical experience of backwashing with RO permeate for UF fouling control treating surface water at low temperatures. Sep Purif Technol 119:136-142 (2013)

26 Sripui J, Pradistsuwana C, Kerr WL and Pradipasena P, Effects of particle size and its distribution on specific cake resistance during rice wine microfiltration. J Food Eng 105:73-78 (2011).

27 Zularisam AW, Ismail AF and Salim R, Behaviours of natural organic matter in membrane filtration for surface water treatment - a review. Desalination 194:211-231 (2006).

28 Neubrand W, Vogler S, Ernst M and Jekel M, Lab and pilot scale investigations on membrane fouling during the ultrafiltration of surface water. Desalination 250:968-972 (2010).

29 Jiang T, Kennedy MD, De Schepper V, Nam S-N, Nopens I, Vanrolleghem et al., Characterization of soluble microbial products and their fouling impacts in membrane bioreactors. Environ Sci Technol 44:6642-6648 (2010).

30 American Society for Testing and Materials ASTM. D4189- 07 Standard Test Method for Silt Density Index (SDI) of Water (2007).

31 Salinas Rodríguez SG. Particulate and organic matter fouling of seawater reverse osmosis systems. [Online]. (2011). Available: http://www.crcnetbase.com/doi/book/10.1201/b11609

32 Choi KYJ and Dempsey BA, In-line coagulation with low-pressure membrane filtration. Water Res 38:4271-4281 (2004).

33 Fan L, Nguyen T, Roddick F a. and Harris JL, Low-pressure membrane filtration of secondary effluent in water reuse: pre-treatment for fouling reduction. J Membr Sci 320:135-142 (2008).

34 Doyen W, Vandaele R, Molenberghs, B. Crompphout J, Bielen P and Baée B, Description of different effects of in-line coagulation upon semi-dead end ultrafiltration. Water Sci Technol Water Supply 3:337-344 (2003).

35 Lai CH, Chou YC and Yeh HH, Assessing the interaction effects of coagulation pretreatment and membrane material on UF fouling control using HPSEC combined with peak-fitting. J Membr Sci 474:207-214 (2015).

36 Konieczny K, Sąkol D, Płonka J, Rajca M and Bodzek M, Coagulation - ultrafiltration system for river water treatment. Desalination 240:151 - 159 (2009).

37 Kim SH, Moon SY, Yoon CH, Yim SK and Cho JW, Role of coagulation in membrane filtration of wastewater for reuse. Desalination. 173:301-307 (2005)

38 Pikkarainen AT, Judd SJ, Jokela J and Gillberg L, Pre-coagulation for microfiltration of an upland surface water. Water Res. 38:455-465 (2004).

39 Edzwald JK and Haarhoff J, Seawater pretreatment for reverse osmosis: chemistry, contaminants, and coagulation. Water Res 45:5428-5440 (2011).

40 Domínguez JR, De Heredia JB, González T and Sanchez-Lavado F, Evaluation of ferric chloride as a coagulant for cork processing wastewaters. Influence of the operating conditions on the removal of organic matter and settleability parameters. Ind Eng Chem Res 44:6539-6548 (2005).

41 Fitzpatrick CSB, Fradin E and Gregory J, Temperature effects on flocculation, using different coagulants. Water Sci Technol 50:171-175 (2004).

42 Tabatabai SAA, Kennedy MD, Amy GL and Schippers JC, Optimizing inline coagulation to reduce chemical consumption in MF/UF systems. Desalin Water Treat 6:94-101 (2009).

43 Boulestreau M and Miehe U, State of the art of the effect of coagulation and ozonation. [Online]. 2010. Available: http://www.kompetenzwasser.de/fileadmin/user_upload/images/forschung/OXERAM/ D_3.3_Report_on_ozonation_and_coagulation_OXERAM_1_.pdf

44 Judd SJ and Hillis P, Optimisation of combined coagulation and microfiltration for water treatment. Water Res 35:2895-2904 (2001).

45 Meyn T and Leiknes T, Comparison of optional process configurations and operating conditions for ceramic membrane MF coupled with coagulation/flocculation pre-treatment for the removal of NOM in drinking water production. J Water Supply Res Technol - AQUA 59:81-91 (2010). 
46 Wang J, Pan S and Luo D, Characterization of cake layer structure on the microfiltration membrane permeability by iron pre-coagulation J Environ Sci (China) 25:308-315 (2013).

47 Barbot E, Moustier S, Bottero JY and Moulin P, Coagulation and ultrafiltration: understanding of the key parameters of the hybrid process. J Membr Sci 325:520-527 (2008).

48 Wiesner MR, Clark MM and Mallevialle J, Membrane filtration of coagulated suspensions. J Environ Eng 115:20-40 (1989).

49 Futselaar H, Spenkelink F and Blankert B, Dynamic control of an ultrafiltration process: coagulant optimisation, in Membranes in Drinking Water Production and Wastewater Treatment. Toulousse, France (2008).

50 Taniguchi M, Kilduff JE and Belford G, Modes of natural organic matter fouling during ultrafiltration. Environ Sci Technol 2003;37: 1676-1683 (2003)

51 Hlavacek $\mathrm{M}$ and Bouchet $\mathrm{F}$, Constant flowrate blocking laws and an example of their application to dead-end microfiltration of protein solutions. J Membr Sci 82:285-96 (1993).
52 Iritani E, A review on modeling of pore-blocking behaviors of membranes during pressurized membrane filtration. Dry Technol 31:146-162 (2013).

53 Jermann D, Pronk W and Boller M, Mutual influences between natural organic matter and inorganic particles and their combined effect on ultrafiltration membrane fouling. Environ Sci Technol 42:9129-9136 (2008).

54 Heijman SGJ, Kennedy MD and van Hek GJ, Heterogeneous fouling in dead-end ultrafiltration. Desalination 178(1-3 Special Issue):295-301 (2005).

55 Gibert O, Lefèvre B, Teuler A, Bernat X and Tobella J, Distribution of dissolved organic matter fractions along several stages of a drinking water treatment plant. J Water Process Eng 6:64-71 (2015).

56 Zupančič M, Novak D, Diaci J and Golobič I, An evaluation of industrial ultrafiltration systems for surface water using fouling indices as a performance indicator. Desalination 344:321-328 (2014). 